Article

\title{
Potential of Oil Palm (Elaeisguineensis) Empty Fruit Bunch Fibres Cement Composites for Building Applications
}

\author{
Temidayo E. Omoniyi \\ Department of Wood Products Engineering, University of Ibadan, Ibadan 200284, Nigeria; \\ temidayoomoniyi@gmail.com
}

Received: 25 January 2019; Accepted: 27 March 2019; Published: 2 April 2019

check for updates

\begin{abstract}
This study was designed to evaluate the physical and mechanical properties of cement-bonded composite made from oil palm (Elaeisguineensis) empty fruit bunch (OPEFB) fibres. The production variables investigated were pre-treatment of fibres with water at varying temperatures (cold, $60{ }^{\circ} \mathrm{C}$ and $100{ }^{\circ} \mathrm{C}$ ), five chemical additive $(\mathrm{NaOH})$ concentrations $(2 \%, 4 \%, 6 \%, 8 \%$, and $10 \%)$, OPEFB fibres ash content at three cement replacement levels $(10 \%, 20 \%$, and $30 \%)$ and three fibre contents $(5 \%, 10 \%$, and $15 \%)$ by weight of cement. The composites were tested for modulus of elasticity (MOE), modulus of rupture (MOR), internal bonding strength (IBS), compressive strength, density, thickness swelling (TS), and water absorption (WA). The pre-treatment of fibre with water at a temperature of $60{ }^{\circ} \mathrm{C}$ and a $\mathrm{NaOH}$ concentration of $8 \%$ significantly enhanced and modified the performance of the composites. It increased MOE (from 5.5 to $8.9 \mathrm{GPa}$ ) and MOR (from 3.6 to 7.3 MPa), and decreased WA (from 26.2 to $12.8 \%$ ) and TS (from 2.5 to $0.5 \%$ ). The results revealed that pre-treatment of fibres, partially replacing cement with OPEFB fibre ash and fibre contents had a marked influence on the properties of the composite board produced $(p<0.05)$. It was concluded that pre-treatment of OPEFB fibres, when optimised, enhanced the sorption resistance and some mechanical properties of the cement composite.
\end{abstract}

Keywords: oil palm; cement-bonded composite; fibre pre-treatment; sodium hydroxide

\section{Introduction}

One of the most abundant agricultural wastes in Nigeria is the by-product of oil palm processing factories, which is oil palm empty fruit bunch (OPEFB) fibre. The OPEFB consists of a bunch of fibres readily available at low cost [1]. OPEFB fibres are extracted by a retting process from empty fruit bunch. The fibres can also be converted to useful products such as fuel, fertilizer, and mulching materials. However, OPEFB fibre presents considerable emission problems when used as fuel [2]. A natural fibre-cement composite has been used extensively in construction materials and processes such as insulating, cladding, noise barriers, and house building [3]. The use of agricultural residues is preferable to virgin natural fibres due to environmental concerns. Most agricultural wastes are low-cost, lightweight, biodegradable, and environmentally friendly, and are obtained from renewable sources [4].

Plant fibres are of biological and lignocellulosic origin which are composed of chemical constituents (lignin, tannins resins, salts, silica, waxes, and ash) and polysaccharides (soluble sugar, starches, cellulose, and hemicelluloses), some of which impair the reaction between the woody element and inorganic cement binder as well as affect cement curing and setting time [5]. Also, the inherent susceptibility of cellulosic fibres to moisture expansion is one of the obstacles of a natural fibre reinforced composite. The presence of high amounts of hydroxyl-groups, mainly in the amorphous regions of hemicelluloses in the cell wall of the natural fibre will lead to relatively high moisture 
sorption, dimensional instability, and rotting. As a consequence, composite properties incorporating natural fibres are affected negatively [6]. This study is therefore designed to evaluate the effects of OPEFB fibre pre-treatments, OPEFB fibre-cement ratios and partial cement substitution by OPEFB fibre ash on the composite properties.

\section{Materials and Methods}

\subsection{Collection and Preparation of Materials}

The materials used were oil palm empty fruits bunch (Figures 1 and 2), normal Portland cement (OPC-53 grade), sodium hydroxide and clean river sand with a maximum size particle of $2 \mathrm{~mm}$. In all cases the cement sand ratio was 1:3. Potable water was used for mixing and the amount used was computed from Papadopoulous' equation [7].

$$
\mathrm{W}_{\mathrm{t}}=0.6 \mathrm{C}_{\mathrm{t}}+(0.3+\mathrm{MC}) \mathrm{W}
$$

where $\mathrm{W}_{\mathrm{t}}=$ weight of water $(\mathrm{g}), \mathrm{C}_{\mathrm{t}}=$ weight of cement $(\mathrm{g}), \mathrm{MC}=$ moisture content of fibre $(\%), \mathrm{W}=$ dry weight of the fibres (g).

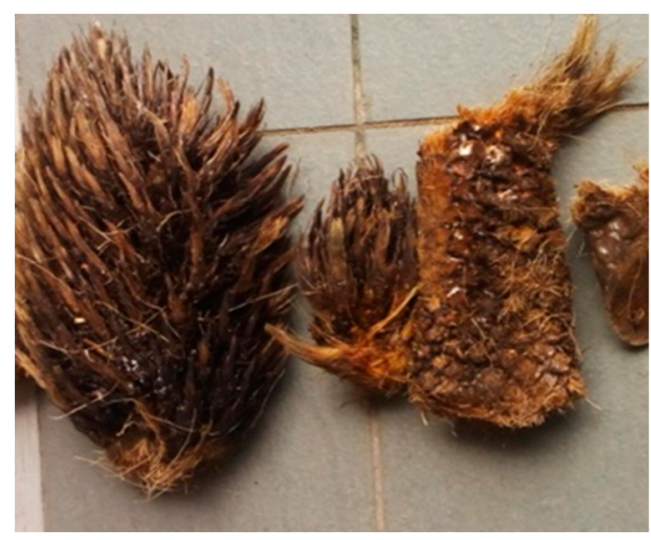

Figure 1. Oil palm empty fruit bunch fibres.

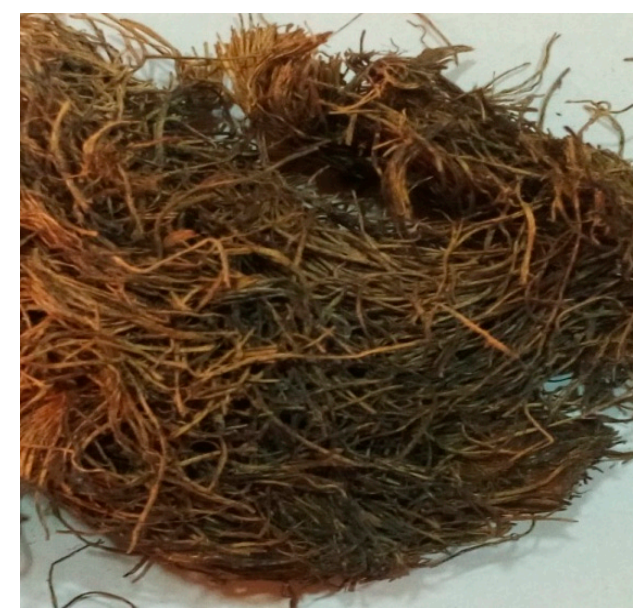

Figure 2. Processed oil palm empty fruit bunch fibres.

\subsubsection{Oil Palm Empty Fruit Bunch Collection and Preparation}

Oil palm empty fruit bunch was collected from an oil palm processing factory in Okitipupa, Ondo State, Nigeria as shown in Figure 1. The bunch was air-dried at ambient temperature in the Department of Wood Products Engineering, University of Ibadan, for two weeks to attain $8.0 \%$ moisture content. The bunch was manually separated and cut into fibres of 15 to $20 \mathrm{~mm}$ in length (Figure 2). 
Some processing and pre-treatment options were considered to achieve viable utilization of the fibres in inorganic-based composites.

2.1.1.1. Pre-Treatment of the Oil Palm Empty Fruit Bunch Fibres with Potable Water at Varying Temperature

For cold water treatment, the fibres were soaked in potable cold water for two weeks at ambient temperature as shown in Figure 3. The water was replaced with fresh potable water daily to facilitate better removal of the soluble extractives. The fibres were subsequently rinsed with clean water until all extrudes were removed, air-dried for one week in laboratory under room temperature and pressure, and batched. For hot water treatment, the fibres were soaked in water at different water temperatures of $60{ }^{\circ} \mathrm{C}$ and $100{ }^{\circ} \mathrm{C}$ for two hours. The water was decanted, and the fibres were rinsed and air-dried until the moisture of $12 \%$ was attained [8].

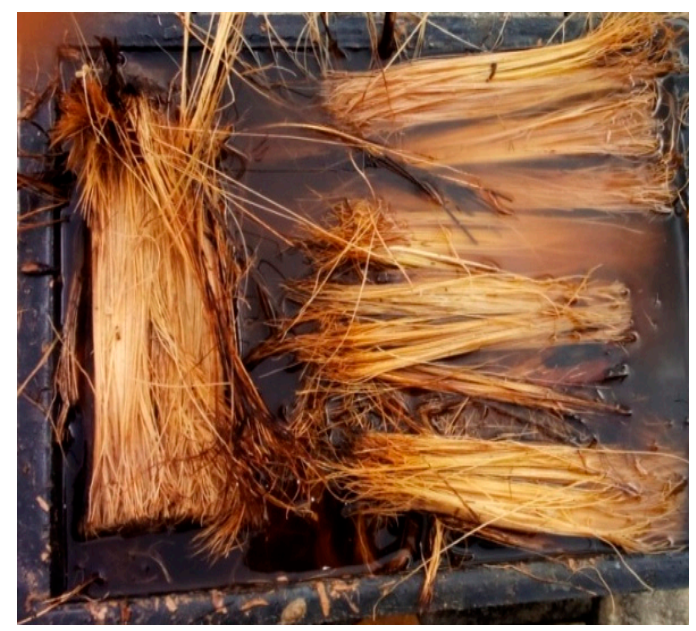

Figure 3. Oil palm empty fruit bunch fibres soaked in water.

\subsubsection{Pre-Treatment of Oil Palm Empty Fruit Bunch Fibres with Sodium Hydroxide Solution}

The fibres were soaked in sodium hydroxide solution at five different concentrations of $2 \%, 4 \%$, $6 \%, 8 \%$, and $10 \%$ by weight of water for $24 \mathrm{~h}$ at a relative humidity of $65 \pm 1 \%$ and a temperature of $20 \pm 3{ }^{\circ} \mathrm{C}$. Thereafter the fibres were rinsed thoroughly with potable water until the extrudes were removed, air-dried, and batched.

\subsubsection{Ashing the Oil Palm Fibres for Partial Replacement of Cement}

The OPEFB fibre was ashed in a muffle furnace at a temperature of $500{ }^{\circ} \mathrm{C}$ in a laboratory until milky white colour was achieved indicating there was no un-burnt carbon present. The ash was ground and sieved through a $600 \mu \mathrm{M}$ sieve. It was then used to partially replace cement at four levels of substitutions which were $0 \%$ (control), $10 \%, 20 \%$ and $30 \%$ by weight of cement.

\subsection{Methods}

\section{The Fibre-Cement Composite Production}

The OPEFB fibre-cement composite was produced by dry-mixing the fibres, cement, and sand in a plastic container until a homogenous mixture was achieved. An estimated quantity of water [7] was added and the entire contents were mixed until an acceptable level of uniformity was achieved. The slurry was poured on a plastic sheet in a flat mould $(500 \mathrm{~mm} \times 300 \mathrm{~mm} \times 6 \mathrm{~mm})$ on table vibrator (Figure 4) and spread to cover the entire area and properly levelled. This was then vibrated for $60 \mathrm{~s}$. It was then 'moist cured' for $24 \mathrm{~h}$ and then later cured in water for a total of 28 days. Five replicate samples of each property test were produced. Cubes of $150 \times 150 \times 150 \mathrm{~mm}$ were however produced 
for compressive strength tests. The cement/sand ratio was 1:3 for all samples. The experimental conditions for the production of oil palm empty fruit bunch fibres-cement composite boards are shown in Table 1.

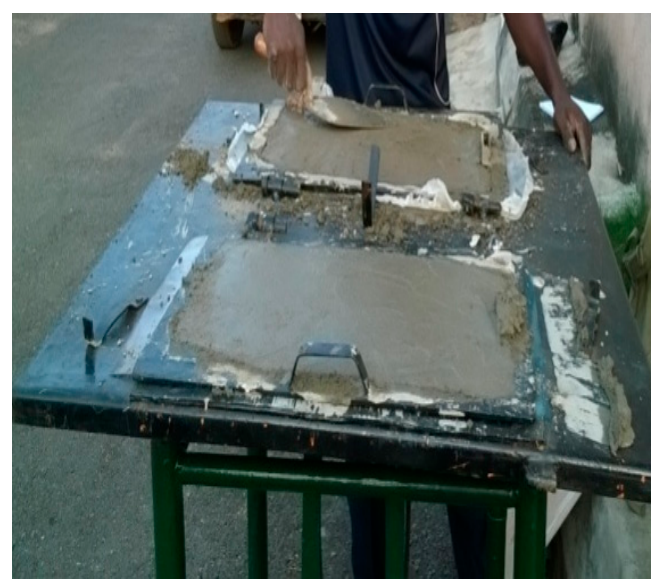

Figure 4. Compaction and vibrating the composite.

Table 1. Production Variables and Specifications.

\begin{tabular}{|c|c|}
\hline Production Variables & Specifications \\
\hline 1. Pre-treatment of fibres with water & Cold, $60^{\circ} \mathrm{C}$, and $100^{\circ} \mathrm{C}$ \\
\hline 2. Chemical additives $(\mathrm{NaOH})$ & $2 \%, 4 \%, 6 \%, 8 \%$ and $10 \%$ \\
\hline 3. Ash-cement content & $10 \%, 20 \%$ and $30 \%$ \\
\hline 4. Fibre-cement content & $5 \%, 10 \%$ and $15 \%$ \\
\hline
\end{tabular}

\subsection{Composite Tests and Test Procedure}

Physical properties (WA and TS) of the composites were carried out in accordance to the established procedure stipulated in [9] and density determination was based on [10]. The mechanical properties comprising internal bonding strength (IBS), modulus of rupture (MOR), and modulus of elasticity (MOE) were determined using an OKH-600 digital display universal testing machine in accordance with [10]. Samples for the flexural tests are shown in Figure 5. The compressive strengths for $150 \mathrm{~mm} \times$ $150 \mathrm{~mm} \times 150 \mathrm{~mm}$ specimens (Figure 6) were determined using a compressive testing machine model ADR Touch 2000 (ELE International) at a speed of $13.5 \mathrm{KN} / \mathrm{s}$ (Figure 7). Five replicates of each test were produced. All property tests results were subjected to analysis of variance at $5 \%$ level of significance.

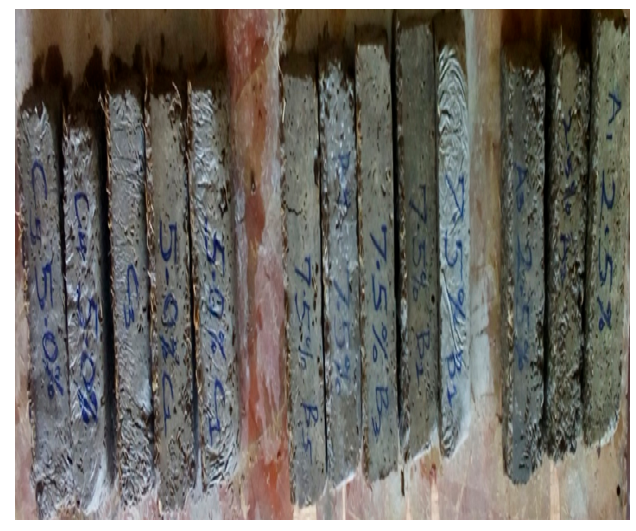

Figure 5. Samples for flexural tests. 


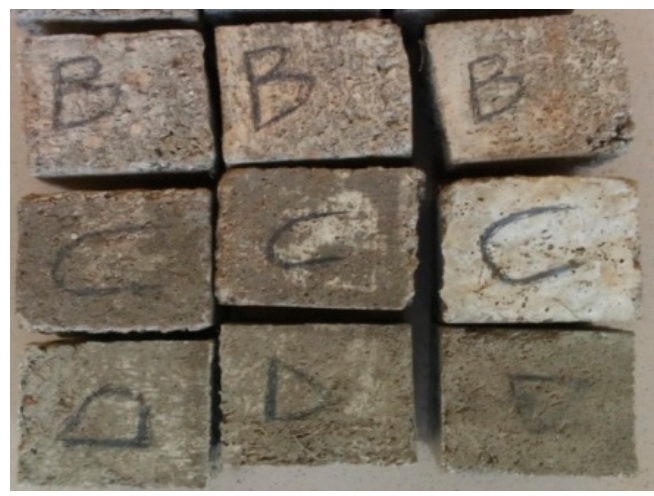

Figure 6. Samples for compressive strength tests.
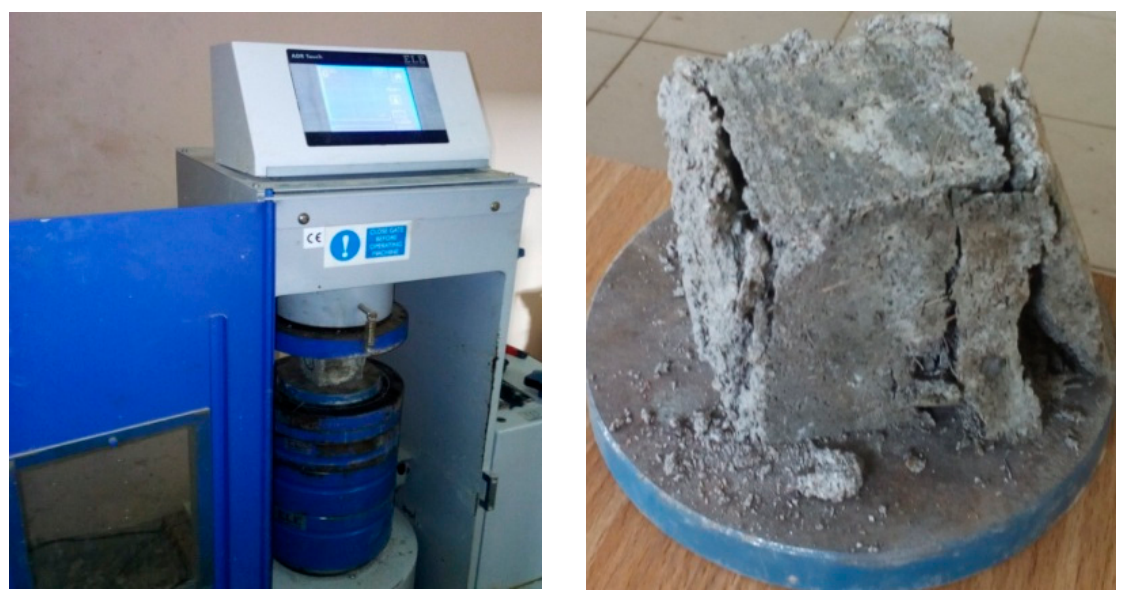

Figure 7. Compressive strength tests.

\section{Results and Discussion}

\subsection{Water Absorption (WA) and Thickness Swelling (TS)}

The water absorption and thickness swelling of the oil palm OPEFB fibre composite are shown in Table 2 while the estimations of WA and TS per percentage of OPEFB fibres are shown in Table 3. The WA and TS of the untreated fibres ranged from 8.8 to $16.4 \%$ and 1.4 to $1.9 \%$, respectively, after $2 \mathrm{~h}$ water immersion and 23.4 to $26.2 \%$ and 1.9 to $2.5 \%$, respectively, after being soaked in water for $24 \mathrm{~h}$. The high sorption properties (WA and TS) observed show that composites produced with untreated fibres are unsuitable for outdoor applications. The values of WA and TS obtained for treated fibres ranged from 4.8 to $6.2 \%$ and 0.2 to $0.7 \%$, respectively, for $2 \mathrm{~h}$ water immersion and 13.9 to $17.9 \%$ and 0.3 to $0.9 \%$, respectively, after water soaking for $24 \mathrm{~h}$. It was generally observed that WA and TS decreased when temperature of water used for the pre-treatment increased. This could be attributed to higher removal of lignin, pectin, and hemicelluloses contents in OPEFB fibres which act as inhibiting substances to fibre-matrix bonding. The treated fibres values are comparable with those of $[5,11,12]$. The WA values agreed favourably with the findings of $[11,13,14]$ on natural fibre reinforced cement composite. It was generally observed that the boards with treated fibres were dimensionally stable due to low WA and TS, hence they are suitable for interior and exterior applications. Duncan's multiple tests revealed that pre-treatments of the fibres significantly $(p<0.05)$ influenced water absorption. 
Table 2. Effects of pre-treatment and fibre contents on composite properties.

\begin{tabular}{|c|c|c|c|c|c|}
\hline \multirow{2}{*}{ Fibre Treatment } & \multirow{2}{*}{ Fibre Content (\%) per Cement Weight } & \multicolumn{2}{|c|}{ Water Absorption (\%) } & \multicolumn{2}{|c|}{ Thickness Swelling (\%) } \\
\hline & & $2 \mathrm{~h}$ & $24 \mathrm{~h}$ & $2 \mathrm{~h}$ & $24 \mathrm{~h}$ \\
\hline \multirow{3}{*}{ Untreated fibre } & 2.5 & 8.8 & 23.4 & 1.4 & 1.9 \\
\hline & 5 & 10.2 & 25.9 & 1.6 & 2.3 \\
\hline & 7.5 & 16.4 & 26.2 & 1.9 & 2.5 \\
\hline \multirow{3}{*}{ Cold water } & 2.5 & 5.5 & 14.6 & 0.3 & 0.4 \\
\hline & 5 & 5.8 & 16.1 & 0.5 & 0.6 \\
\hline & 7.5 & 6.2 & 17.9 & 0.7 & 0.9 \\
\hline \multirow{3}{*}{ Water treated @ $60^{\circ} \mathrm{C}$} & 2.5 & 5.3 & 14.2 & 0.3 & 0.3 \\
\hline & 5 & 5.7 & 14.9 & 0.4 & 0.4 \\
\hline & 7.5 & 5.6 & 16.2 & 0.5 & 0.6 \\
\hline \multirow{3}{*}{ Water treated @ $100{ }^{\circ} \mathrm{C}$} & 2.5 & 4.8 & 13.9 & 0.2 & 0.3 \\
\hline & 5 & 5.1 & 14.7 & 0.3 & 0.4 \\
\hline & 7.5 & 5.2 & 15.4 & 0.5 & 0.6 \\
\hline \multirow{3}{*}{$\mathrm{NaOH}(8 \%)$} & 2.5 & 4.4 & 11.4 & 0.2 & 0.3 \\
\hline & 5 & 4.5 & 12.3 & 0.3 & 0.4 \\
\hline & 7.5 & 4.5 & 12.8 & 0.3 & 0.5 \\
\hline
\end{tabular}

Table 3. Estimation of water absorption (WA) and thickness swelling (TS) per \% of oil palm empty fruit bunch (OPEFB) fibres in the cement composites.

\begin{tabular}{|c|c|c|c|c|c|}
\hline Fibre Treatment & $\begin{array}{l}\text { Fibre Content (\%) } \\
\text { per Cement Weight }\end{array}$ & $\begin{array}{l}\text { WA per } \% \text { of } \\
\text { Fibre at } 2 \mathrm{~h}\end{array}$ & $\begin{array}{l}\text { WA per } \% \text { of } \\
\text { Fibre at } 24 \mathrm{~h}\end{array}$ & $\begin{array}{l}\text { TS per } \% \text { of } \\
\text { Fibre at } 2 \mathrm{~h}\end{array}$ & $\begin{array}{l}\text { TS per } \% \text { of } \\
\text { Fibre at } 24 \mathrm{~h}\end{array}$ \\
\hline \multirow{3}{*}{ Untreated fibre } & 2.5 & 3.5 & 9.4 & 0.56 & 0.76 \\
\hline & 5 & 2.0 & 5.2 & 0.32 & 0.46 \\
\hline & 7.5 & 2.2 & 3.5 & 0.25 & 0.33 \\
\hline \multirow{3}{*}{ Cold water } & 2.5 & 2.2 & 5.8 & 0.12 & 0.16 \\
\hline & 5 & 1.2 & 3.2 & 0.10 & 0.12 \\
\hline & 7.5 & 0.8 & 2.4 & 0.09 & 0.12 \\
\hline \multirow{3}{*}{ Water treated @ $60{ }^{\circ} \mathrm{C}$} & 2.5 & 2.1 & 5.7 & 0.12 & 0.12 \\
\hline & 5 & 1.1 & 3.0 & 0.08 & 0.08 \\
\hline & 7.5 & 0.7 & 2.2 & 0.07 & 0.08 \\
\hline \multirow{3}{*}{ Water treated @ $100{ }^{\circ} \mathrm{C}$} & 2.5 & 1.9 & 5.6 & 0.08 & 0.12 \\
\hline & 5 & 1.0 & 2.9 & 0.06 & 0.08 \\
\hline & 7.5 & 0.7 & 2.1 & 0.07 & 0.08 \\
\hline \multirow{3}{*}{$\mathrm{NaOH}(8 \%)$} & 2.5 & 1.8 & 4.6 & 0.08 & 0.12 \\
\hline & 5 & 0.9 & 2.5 & 0.06 & 0.08 \\
\hline & 7.5 & 0.6 & 1.7 & 0.04 & 0.07 \\
\hline
\end{tabular}

The effects of additives levels on OPEFB fibre cement bonded composites are shown in Figures 8 and 9. These revealed a gradual decrease in WA and TS as $\mathrm{NaOH}$ levels increased (from 0 to $10 \%$ ). The higher the $\mathrm{NaOH}$ levels, the lower the WA and TS of the composite. The decrease in the WA and TS comparable to the increase in $\mathrm{NaOH}$ levels ranged from 10.2 to $4.4 \%$ and 1.6 to $0.2 \%$ for $2 \mathrm{~h}$, respectively, and 25.9 to $12.0 \%$ and 2.3 to $0.3 \%$ for $24 \mathrm{~h}$, respectively as shown in Figures 9 and 10 . Significant differences $(p<0.05)$ were observed between additives levels and dimensionality stability of the composites. The values of WA and TS for OPEFB fibres pre-treated with $8 \% \mathrm{NaOH}$ are shown in Table 2. The values were significantly lower than the untreated and water treated composites. The reasons for this observation could be that the alkaline treatment $(\mathrm{NaOH})$ modified the surface of OPEFB fibres, thereby increasing the surface roughness and hence improving the dimensional stability of the composites. 


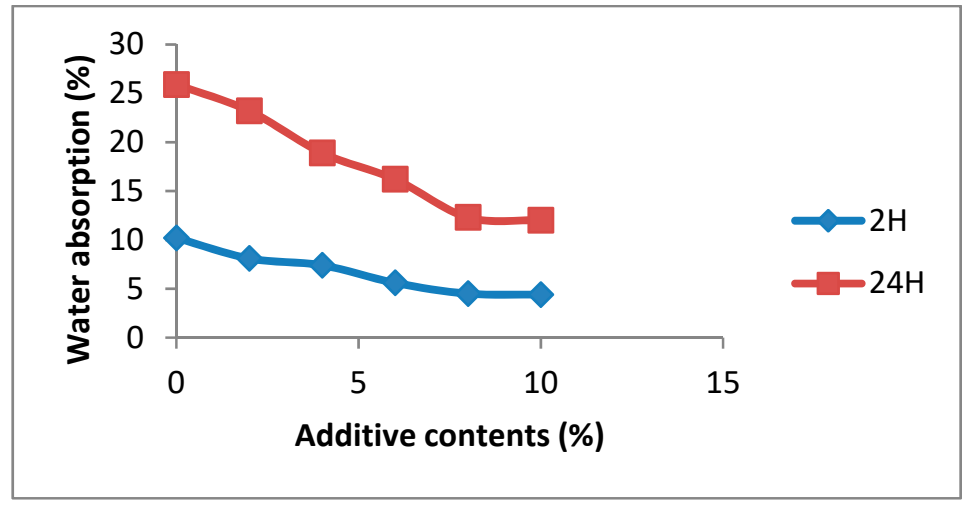

Figure 8. Effect of $\mathrm{NaOH}$ levels (\%) on water absorption (WA) of OPEFB fibre-cement bonded composites.

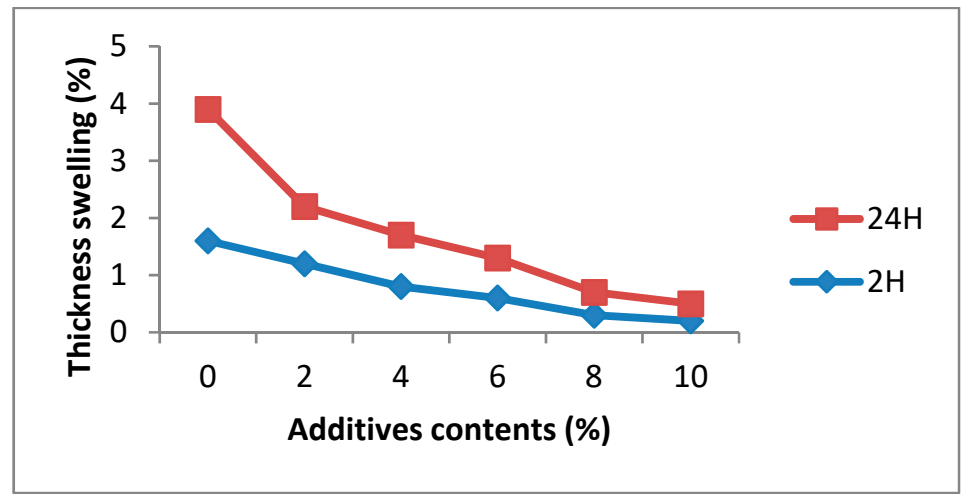

Figure 9. Effect of $\mathrm{NaOH}$ levels (\%) on thickness swelling (TS) of OPEFB fibre-cement bonded composites.

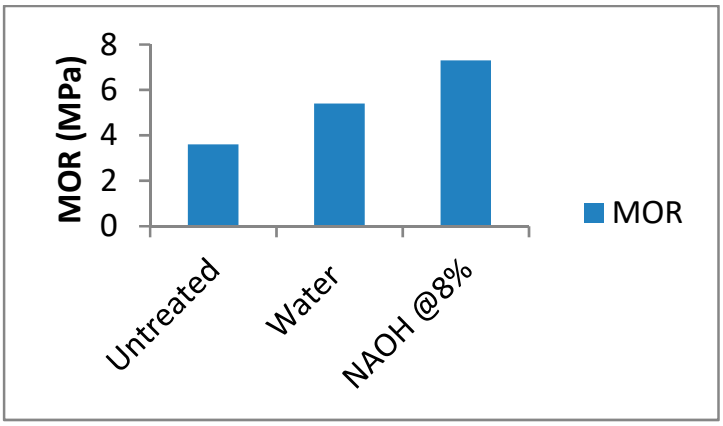

Figure 10. Modulus of rupture (MOR) of untreated and pre-treated OPEFB fibre-cement composite.

\subsection{Density of Composites}

The densities of the composites produced with different $\mathrm{NaOH}$ concentration treatments are shown in Table 4 . The oven dry densities ranged from 1550 to $1694 \mathrm{kgm}^{-3}$. The densities increased with an increase in $\mathrm{NaOH}$ concentration until $8 \%$ concentration was reached with a significant reduction in density. This could be due to a higher concentration of $\mathrm{NaOH}$ resulting in excess delignification, weaker, or damaged fibres. According to [15], alkali treatment led to the dissolution of the lignin layer on the OPEFB fibre and better orientation and packing of the molecules. Most samples have a density below $1680 \mathrm{kgm}^{-3}$ which is categorized by ASTM C90 as lightweight concrete blocks. The densities of the composite with different ash contents are shown Table 5. The mean oven dry density values ranged between 1678 and $1997 \mathrm{kgm}^{-3}$, while the control value was $2311 \mathrm{kgm}^{-3}$. There was an observable decrease in the density of the composite as ash content increased and the differences were significant $(p<0.05)$, as shown in Table 6. Hence, the higher the ash content, the lighter the composite produced. Bulk densities increased as the days of curing increase. This is in line with [8,16]. As ash content increased, the compressive strength reduced. However, compressive strength increased with an 
increase in curing days. Compressive strength generally increased with curing period and decreased with increased amount of ash. The control still had the highest compressive strength at 28 days.

Table 4. Effects of chemical treatments at different levels of $\mathrm{NaOH}$ concentration on composites properties.

\begin{tabular}{ccccc}
\hline NaOH Content (\%) & Density $\mathbf{~ k g m ~}^{-\mathbf{3}}$ & MOR (MPa) & MOE (GPa) & IBS (MPa) \\
\hline 0 & 1550 & 3.6 & 5.5 & 0.33 \\
2 & 1575 & 3.9 & 6.2 & 0.35 \\
4 & 1580 & 4.5 & 6.3 & 0.37 \\
6 & 1654 & 5.1 & 7.7 & 0.37 \\
8 & 1694 & 7.3 & 8.9 & 0.40 \\
10 & 1683 & 3.8 & 4.1 & 0.33 \\
\hline
\end{tabular}

Table 5. Influence of oil palm empty fruit bunch ash on the bulk density of the composite.

\begin{tabular}{cccc}
\hline \multirow{2}{*}{ Percentage of Ash (\%) } & \multicolumn{3}{c}{ Mean Oven Dry Density $\left(\mathbf{k g m}^{-\mathbf{3}}\right)$} \\
\cline { 2 - 4 } & $\mathbf{7}$ days & $\mathbf{1 4}$ days & $\mathbf{2 8}$ days \\
\hline 0 & 2216 & 2297 & 2311 \\
5 & 1750 & 1882 & 1997 \\
10 & 1732 & 1827 & 1895 \\
15 & 1691 & 1791 & 1803 \\
20 & 1680 & 1688 & 1756 \\
25 & 1654 & 1678 & 1704 \\
30 & 1628 & 1649 & 1678 \\
\hline
\end{tabular}

Table 6. Influence of fibres contents on mechanical properties of the composite.

\begin{tabular}{|c|c|c|c|}
\hline Percentage of Fibre (\%) & Compressive Strength ( $\left.\mathrm{MPa} \mathrm{N} / \mathrm{mm}^{2}\right)$ & MOR (MPa) & MOE (GPa) \\
\hline 0 (Plain) & 15.02 & 3.5 & 5.5 \\
\hline 2.5 & 13.26 & 3.7 & 5.8 \\
\hline 5.0 & 12.65 & 4.9 & 6.5 \\
\hline 7.5 & 10.98 & 4.1 & 3.4 \\
\hline
\end{tabular}

\subsection{The Mechanical Properties}

The mechanical properties tested were modulus of rupture (MOR), modulus of elasticity (MOE), internal bonding strength (IBS) and compressive strength. Figure 10 shows the MOR for untreated and treated OPEFB fibre-cement composite. The same trend was observed for MOE and IBS. It was observed that the untreated fibre-cement composite had the lowest MOR, MOE, and IBS of 3.6 MPa, $5.5 \mathrm{GPa}$, and $0.33 \mathrm{MPa}$, respectively, which connotes weak compatibility between the fibre and the matrix. This was probably due to the presence of inhibiting substances such as pectin and waxy substances which prevented the hydroxyl groups from forming interfacial adhesion with the matrices [15]. Treatment of fibres with water enhanced the strength properties, however the highest increment in MOR, MOE, and IBS was achieved by pre-treatment of fibre with a solution of $8 \% \mathrm{NaOH}$. The MOR of the composites ranged between 3.6 MPa for the untreated composite to 7.3 MPa when treated with $8 \% \mathrm{NaOH}$ concentration to an increment of more than $100 \%$. The MOE increased from 4.4 GPa for the untreated OPEFB fibre to $8.9 \mathrm{GPa}$ for $8 \% \mathrm{NaOH}$ treated fibre. Generally, MOR and MOE increased with an increase in $\mathrm{NaOH}$ concentration, probably due to the influence of $\mathrm{NaOH}$ on cellulosic fibril, the degree of polymerization, and the extraction of lignin and hemi-cellulosic compounds [15]. According to [17] another possible reasons for this kind of behaviour may be due to the modification of the fibre by decreasing the spiral angle and increasing in the molecular orientation, thereby introducing randomness in the orientation of the crystallites due to non-cellulosic matter resulting in the improvement of fiber-matrix bonding. This observation was also in line with the report of $[11,12,18]$ that increments in chemical additive concentration and cement content improved the 
bonding between lignocellulosic particles and cement. This was also in agreement with the findings of [19-21]. However, a negative trend was observed when the fibre was pre-treated with $\mathrm{NaOH}$ concentration of more than eight percent. The values of MOR and MOE decreased significantly, by $48 \%$ and $62 \%$, respectively, whereas the effect on IBS was not significant. This could also be due to higher concentration of $\mathrm{NaOH}$ resulting in excess delignification, weaker, or damaged fibres. Table 6 shows the influence of fibre contents on the mechanical properties of the composites. It was observed that MOR and MOE increased as fibre content increased. However, at higher fibre addition (7.5\% by weight of cement) there was a significant decrease in the MOR and MOE which may be due to fibre entanglement and agglomeration. The compressive strength decreased with an increase in fibre content, probably due to less efficient packing of the fibres and matrix that caused the void volume to increase, followed by a decrease in density and lower compressive strength as shown in Table 7 . The values were in line with compressive strength for plain concrete as shown in Table 8.

Table 7. Effects of ash contents on the compressive strength of ash-cement composite boards.

\begin{tabular}{|c|c|c|c|}
\hline \multirow{2}{*}{ Percentage of Ash (\%) } & \multicolumn{3}{|c|}{ Mean Compressive Strength $\left(\mathrm{N} / \mathrm{mm}^{2}\right)$} \\
\hline & 7 days & 14 days & 28 days \\
\hline 0 & 11.58 & 13.36 & 15.22 \\
\hline 5 & 10.26 & 10.54 & 10.89 \\
\hline 10 & 8.45 & 8.89 & 9.46 \\
\hline 15 & 7.97 & 8.16 & 8.63 \\
\hline 20 & 6.54 & 72 & 7.42 \\
\hline 25 & 6.10 & 6.44 & 6.85 \\
\hline 30 & 5.40 & 5.94 & 6.63 \\
\hline
\end{tabular}

Table 8. Recommended grade of concrete [21].

\begin{tabular}{ccc}
\hline Grade & Compressive Strength & Concrete Class \\
\hline 7 & 5 & Plain concrete \\
10 & 10 & Reinforced concrete with light weight aggregate \\
15 & 15 & Reinforced Concrete with dense aggregate \\
20 & 20 & \\
25 & 25 & \\
\hline
\end{tabular}

\section{Conclusions}

Oil palm empty fruit bunch fibre-cement composites were produced. The physical and mechanical properties were investigated as functions of OPEFB fibres pre-treatment in water at different temperatures, as well as in a solution containing sodium hydroxide at different concentrations. The fibres were also ashed and used as partial replacement of cement in the composite. The results obtained showed that:

(1) Pre-treatment of fibre with water at temperature of $60{ }^{\circ} \mathrm{C}$, as well as a treatment in $8 \% \mathrm{NaOH}$ concentration, increased $\mathrm{MOE}$ from 5.5 to $8.9 \mathrm{GPa}$ and MOR from 3.6 to $7.3 \mathrm{MPa}$, and decreased WA from 26.2 to $12.8 \%$ and TS from 2.5 to $0.5 \%$.

(2) There were also significant differences in WA and TS values when untreated and pre-treated OPEFB fibres were used for cement composite production. Low values of WA and TS obtained for the pre-treated fibres indicated that the composites produced were dimensionally stable and could be used for both interior and exterior applications.

(3) Density and compressive strength decreased as fibre contents increased. The fibre-cement composites can be used to produce lightweight blocks of densities less than $1680 \mathrm{kgm}^{-3}$

(4) The concrete class of the sample made with oil palm empty fruit bunch fibre was reinforced concrete with light weight aggregates, in accordance with [21] as shown in Table 8. 
Funding: This research received no external funding.

Conflicts of Interest: The author declares no conflict of interest.

\section{References}

1. Hassan, A.I.; Arshad, A.S.; Nasir, F.; Baka, A.A. A Review on Oil Palm Empty Fruit Bunch Fiber-Reinforced Polymer Composite Materials. Polym. Compos. 2010, 31, 2079-2101. [CrossRef]

2. Onuorah, O.E. Properties of Fibre-boards Made from Oil Palm (Elaeis guineensis) Stem and/or Mixed Tropical Hardwood Sawmill Residues. J. Trop. For. Sci. 2005, 17, 497-507.

3. Ajayi, B. The use of Coconut fibre, a non-convectional material for inorganic bonded Manufacturing: Mitigating approach to scare housing products. In Proceedings of the 1 Pro-African Conference: Non-conventional Building Materials Based on Agro-industrial Wastes, Pirassununga, São Paulo, Brazil, 18-19 October 2010; pp. 66-169.

4. Olorunnisola, A.O. Strength and Water absorption characteristics of cement bonded particleboard produced from coconut husk. J. Civ. Eng. Res. Pract. 2006, 31, 41-49. [CrossRef]

5. Ajayi, B.; Olufemi, B. Properties of cement-bonded flake-boards from Gmelina arborea and Leucaena leucocephala. Int. J. Biol. Chem. Sci. 2010, 5, 586-594. [CrossRef]

6. Raju, G.U.; Kumarapa, S.; Gaitonde, V.N. Mechanical and physical characterization of agricultural waste reinforced polymer composites. J. Mater. Environ. Sci. 2012, 3, 907-916.

7. Papadopoulus, A.N.; Ntalos, G.A.; Karakas, I. Mechanical and physical properties of Cement-Bonded OSB. Holz Roh Werkst. 2006, 64, 517-518. [CrossRef]

8. Khorami, M.; Ganjian, E. Comparing flexural behaviour of fibre-cement composites reinforced bagasse: Wheat and eucalyptus. Constr. Build. Mater. 2011, 24,187-192. [CrossRef]

9. American Society for Testing and Materials. Annual Book of ASTM Standards; ASTM D 570-98, reapproved in 2005; American Society for Testing and Materials: West Conshohocken, PA, USA, 2005; pp. 35-37.

10. American Society for Testing and Materials. Standard Specification for Fibre Cement Roofing Shingles, Shakes, ASTM International; American Society for Testing and Materials: West Conshohocken, PA, USA, 2012.

11. Olorunnisola, A.O.; Pitman, A.; Mansfield-William, H. Hydration characteristics of cement-bonded composites made from rattan cane and coconut husk. J. Bamboo Ratt. 2005, 42, 193-201. [CrossRef]

12. Olorunnisola, A.O. Effects of particle geometry and chemical accelerator on strength properties of rattan-cement composites. Afr. J. Sci. Eng. 2007, 8, 22-27.

13. Olorunnisola, A.O.; Adefisan, O.O. Trial production and testing of cement-bonded Particle board from rattan furniture waste. Wood Fibre Sci. 2002, 34, 116-124.

14. Olorunnisola, A.O.; Agrawal, S. Effects of $\mathrm{NaOH}$ concentration and fibre content on physio-mechanical properties of cement-bonded rattan fibre composites. Pro Ligno 2015, 11, 192-198.

15. Tan, C.; Ahmad, I.; Heng, M. Characterization of polyester composites from recycled polyethylene terephthalate reinforced with empty fruit bunch fibers. Mater. Des. 2011, 32, 4493-4501. [CrossRef]

16. Mrema, A.L. Cement Bonded Wood Wool Boards from Podocarpus species for low cost housing. J. Civ. Eng. Res. Pract. 2006, 31, 51-64.

17. Sreekala, M.S.; Thomas, S. Utilization of Short Oil Palm Empty Fruit Bunch Fiber (OPEFB) as a Reinforcement in Phenol-formaldehyde resins: Studies on Mechanical properties. J. Polym. Eng. 1997, 16, 265-294. [CrossRef]

18. Aggarwal, L.K.; Agrawal, S.P.; Thapliyal, P.C.; Karade, S.R. Cement-bonded composite boards with arhar stalks. Cem. Concr. Comp. 2008, 30, 44-51. [CrossRef]

19. Badejo, S.O.; Omole, A.O.; Fuwape, J.A.; Oyeleye, B.O. Static bending and moisture response of cement bonded Particleboard produced at different levels of percent chemical additive content in board. Niger. J. Agric. Food Environ. 2011, 7, 111-120. 
20. Falemara, B.C.; Ajayi, B.; Agbaje, J.; Binuyo, G. Strength and Dimensional Stability Properties of Cement Bonded Board Produced from Arachis hypogaea (Groundnut) Shell. In Sudano Sahelian Landscape and Renewable Natural Resources Development in Nigeria, Proceedings of the 37th Annual Conference of the Forestry Association of Nigeria, Minna, Niger State, 9-14 November 2014; Forestry Association of Nigeria: Minna, Nigeria, 2014; pp. 496-506.

21. Frybort, S.; Mauritz, R.; Teischinger, A.; Muller, U. Cement Bonded Composites: A Mechanical Review. BioResuorces 2008, 3, 602-626. article distributed under the terms and conditions of the Creative Commons Attribution (CC BY) license (http://creativecommons.org/licenses/by/4.0/). 